\title{
SISTEM INFORMASI AKUNTANSI PENGGAJIAN DAN PENGUPAHAN
}

\author{
Irza Triwahyuni, Nevi Costari, M. Muzaki Wildan G. \\ Irzatriwahyuni3@gmail.com, nevicstr@gmail.com, muhammadmuzaki9999@gmail.com
}

\begin{abstract}
The purpose of this study was to analyze and find out about the accounting information system in the process of payroll and wages. In addition, the purpose of this study is also to determine the effect of an effective and efficient payroll and payroll accounting information system, thus facilitating the payroll and remuneration process. The research method used in the research of payroll and wage accounting information systems is to use qualitative descriptive research methods and literature. An Accounting Information System (AIS) is a system designed to collect and display accounting information so that accountants and company executives can make informed decisions. The results of this study indicate that every government agency needs to implement public sector accounting because it can simplify and improve the quality of presenting financial reports.
\end{abstract}

Keywords: Accounting information system (AIS), payroll and wages

\begin{abstract}
Abstrak
Tujuan dari penelitian ini adalah untuk menganalisis dan mengetahui tentang sistem informasi akuntansi pada proses penggajian dan pengupahan. Selain itu tujuan dari penelitian ini juga, untuk mengetahui pengaruh sistem informasi akuntansi penggajian dan pengupahan yang efektif dan efisien, sehingga memudahkan dalam proses penggajian dan pengupahan. Metode penelitian yang digunakan dalam penelitian sistem informasi akuntansi penggajian dan pengupahan ini adalah dengan menggunakan metode penelitian deskriptif kualitatif dan kepustakaan. Sistem Informasi Akuntansi (SIA) adalah sistem yang dirancang untuk mengumpulkan dan menampilkan informasi akuntansi sehingga akuntan dan eksekutif perusahaan dapat membuat keputusan yang tepat. Hasil dari penelitian ini menunjukkan bahwa setiap instansi pemerintah perlu mengimplementasikan akuntansi sektor publik karena dapat mempermudah dan meningkatkan kualitas dalam menyajikan laporan keuangan.
\end{abstract}

Kata kunci: Sistem informasi akuntansi (SIA), penggajian dan pengupahan

\section{PENDAHULUAN}

Perkembangan teknologi yang semakin meningkat juga mempengaruhi perkembangan kinerja dalam mencapai tujuan perusahaan. Semakin meningkatnya teknologi dalam menjalankan kegiatan operasional tentunya juga harus didukung dengan adanya sumber daya manusia atau karyawan yang berkualitas untuk mendukung tercapainya tujuan utama. Sistem akuntansi disusun secara formal dan berfungsi menyajikan informasi yang berhubungan dengan aktivitas perusahaan. 
Sistem akuntansi yang disusun hendaknya dapat memberikan informasi yang mengandung prinsip prinsip dan teknik pengendalian intern sehingga informasi yang dihasilkan dapat dipercaya keakuratannya. Sistem akuntansi harus dapat membantu manajemen dalam pengendalian operasional perusahaan. Sistem akuntansi penggajian mencakup hal-hal yang berhubungan dengan masalah penggajian karyawan, di antaranya adalah mengenai penggolongan sistem akuntansi penggajian, fungsi-fungsi yang terkait, jaringan prosedur yang membentuk sistem dan dokumendokumen yang digunakan dalam proses penggajian. Sistem akuntansi penggajian karyawan dapat juga memperkecil adanya penyelewengan atau kesalahan yang terjadi dalam perusahaan baik secara sengaja maupun tidak sengaja yang dapat mengakibatkan kerugian bagi perusahaan, dengan kata lain sistem akuntansi penggajian karyawan dapat berfungsi sebagai kontrol dalam kegiatan perusahaan. Sistem pengendalian intern merupakan proses pemantauan yang memungkinkan manajemen mengetahui apakah tindakan yang dilakukan dan bagaimanakah tindakan koreksinya jika pelaksanaan tidak sesuai dengan yang telah ditetapkan semula. Suatu sistem pengendalian intern dikatakan memadai jika dengan diterapkannya sistem tersebut semua tujuan perusahaan dapat tercapai. Tujuan tersebut adalah pengamanan atau menjaga aktiva yang dimiliki, memeriksa ketelitian dan kebenaran data akuntansi, menjamin adanya efisiensi dalam operasional serta menjaga agar tidak terjadi penyimpangan dari kebijakan yang telah ditetapkan, dengan demikian dapat dilihat bahwa sistem pengendalian intern mempunyai peranan yang penting sekali bagi perusahaan.

Kualitas sistem informasi akuntansi yang efektif dan efisien sangat diperlukan bagi sebuah rumah sakit, khususnya pada sistem informasi akuntansi penggajian dan pengupahan. Dikatakan efektif ketika sebuah hal dapat digunakan dan bermanfaat sesuai dengan dasar yang telah ditetapkan, sedangkan dikatakan efisien ketika melakukan sesuatu tersebut dapat meminimalisir atau mengurangi penggunaan biaya yang ada sebelumnya. Segala hal yang berhubungan dengan gaji dan upah harus didukung dengan formulir, catatan atau bukti-bukti pendukung lainnya yang sesuai dengan peraturan yang berlaku secara umum, atau peraturan yang dibuat dan berlaku dalam perusahaan tersebut. Gaji dan upah dalam perusahaan jika disusun dan diimplementasikan secara baik dan benar, maka dapat meningkatkan kepercayaan diri bagi para pegawai, sehingga dapat membuat mereka akan berpikir bahwa gaji dan upah mereka sudah aman, dan semua hal-hal lainnya yang berhubungan dengan penambahan atau pengurangan gaji dan upah dapat mereka ketahui atau laksanakan dengan baik dan benar.

Sistem akuntansi disusun secara formal dan berfungsi menyajikan informasi yang berhubungan dengan aktivitas perusahaan. Sistem akuntansi yang disusun hendaknya dapat 
memberikan informasi yang mengandung prinsipprinsip dan teknik pengendalian intern sehingga informasi yang dihasilkan dapat dipercaya keakuratannya. Sistem akuntansi harus dapat membantu manajemen dalam pengendalian operasional perusahaan. Sistem akuntansi penggajian mencakup hal-hal yang berhubungan dengan masalah penggajian karyawan, di antaranya adalah mengenai penggolongan sistem akuntansi penggajian, fungsi-fungsi yang terkait, jaringan prosedur yang membentuk sistem dan dokumendokumen yang digunakan dalam proses penggajian. Sistem akuntansi penggajian karyawan dapat juga memperkecil adanya penyelewengan atau kesalahan yang terjadi dalam perusahaan baik secara sengaja maupun tidak sengaja yang dapat mengakibatkan kerugian bagi perusahaan, dengan kata lain sistem akuntansi penggajian karyawan dapat berfungsi sebagai kontrol dalam kegiatan perusahaan. (Hidayat, 2013) ${ }^{1}$

Dalam penelitian awal diketahui bahwa sistem penggajian dan pengupahan belum berjalan dengan efektif dan efisien karena terkadang waktu pembayaran gaji masih belum sesuai dengan prosedur waktu yang ada. Penelitian ini hendak mengidentifikasi dan mengevaluasi sistem pengajian dan pengupahan yang sangat berperan penting dalam peningkatan pelayanan rumah sakit. Dengan adanya system informasi akuntansi yang baik dalam sistem penggajian dan pengupahan, maka diharapkan dapat meningkatkan kinerja karyawan dan mengkontrol aktivitas pengeluaran kas. Sistem informasi akuntansi adalah organisasi formulir, catatan, dan pelaporan yang dikoordinasikan sedemikian rupa untuk menyediakan informasi keuangan yang dibutuhkan oleh manajemen guna memudahkan pengelolaan data perusahaan

Sistem pengendalian intern merupakan proses pemantauan yang memungkinkan manajemen mengetahui apakah tindakan yang dilakukan dan bagaimanakah tindakan koreksinya jika pelaksanaan tidak sesuai dengan yang telah ditetapkan semula. Suatu sistem pengendalian intern dikatakan memadai jika dengan diterapkannya sistem tersebut semua tujuan perusahaan dapat tercapai. Tujuan tersebut adalah pengamanan atau menjaga aktiva yang dimiliki, memeriksa ketelitian dan kebenaran data akuntansi, menjamin adanya efisiensi dalam operasional serta menjaga agar tidak terjadi penyimpangan dari kebijakan yang telah ditetapkan, dengan demikian dapat dilihat bahwa sistem pengendalian intern mempunyai peranan yang penting sekali bagi perusahaan.

Untuk menjalankan kegiatannya dengan efektif dan efisien, sebuah perusahaan memerlukan suatu sistem pengolahan data informasi yang mendukungnya. Kebutuhan ini akan terpenuhi dengan adanya sistem informasi akuntansi. Sistem informasi akuntansi harus dirancang dan digunakan secara efektif, karena informasi akuntansi merupakan bagian yang paling penting dari seluruh 
informasi yang diperlukan oleh manajemen. Sistem informas akuntansi dalam perusahaan dapat membantu pihak - pihak manajemen memperoleh informasi yang tepat dalam pengambilan keputusan untuk mencapai tujuan utama perusahaan termasuk dalam hal pemberian atau pembayaran kompensasi kepada karyawan yang berupa gaji dan upah. Biaya gaji dan upah yang jumlahnya cukup besar dapat meningkatkan risiko pengunaan gaji dan upah yang tidak semestinya. (Fibriyanti, 2017)2

\section{KAJIAN TEORI}

\section{A. Sistem Informasi Akuntansi}

Pengertian Sistem Informasi Akuntansi

Sistem Informasi Akuntansi Menurut Romney dan Steinbart merupakan suatu sistem yang mengumpulkan, mencatat, menyimpan, menganalisis dan mengolah data untuk menghasilkan suatu informasi bagi pembuat atau pengambil keputusan. Sistem informasi akuntansi ini meliputi orang, prosedur dan instruksi, data, perangkat lunak, infrastruktur teknologi informasi, serta pengendalian internal dan juga ukuran langkah - langkah keamanan. (Randi.M, 2018) ${ }^{3}$

Sistem informasi akuntansi merupakan suatu sistem informasi yang berbasis komputer dan dirancang untuk mentransformasi data akuntansi menjadi informasi, yang mencakup siklus pemrosesan transaksi, penggguna teknologi informasi, dan pengemban sistem informasi. Puspitawati dan Anggadini (2011:58)

Menurut Turner, Weickgenannt, \& Copeland (2017:4) sistem informasi akuntansimeurpakan suatu yang meliputi proses, prosedur, dan sistem yang menangkap data akuntansi dari proses bisnis, mencatat data akuntansi ke dalam catatan yang sesuai, memproses data akuntansi secara terperinci dengan mengklasifikasikan, merangkum, dan mengkonsolidasikan serta melaporkan data akuntansi yang diringkas ke pengguna internal maupun eksternal.

Kemudian menurut Hall (2011:7) Sistem Informasi Akuntansi merupakan suatu sub sistem yang memproses transaksi keuangan dan non-keuangan yang berpengaruh secara langsung terhadap pemrosesan transaksi keuangan tersebut.

Dari informasi pengertian menurut para ahli di atas, dapat diambil kesimpulan bahwa sistem informasi akuntansi merupakan sistem yang dapat menghasilkan informasi 
dengan melakukan suatu kegiatan mengumpulkan, mencatat, menyimpan, memeroses sampai dengan menghasilkan laporan data akuntansi yang dapat digunakan untuk pengguna mengambil keputusan, baik pengguna internal maupun pengguna eksternal. Selain itu, sistem informasi akuntansi menjadi hal yang sangat penting dalam suatu perusahaan maupun isntansi, karena sistem informai akuntansi membuat setiap proses-proses yang ada di dalam oraganisasi atau perusahaan menjadi lebih efektif, efisien dan terstruktur dengan rapi.

Komponen Sistem Informasi Akuntansi

Terdapat enam komponen sistem informasi akuntansi menurut (Romney \& Steinbart (2018:11), yaitu sebagai berikut :

1) Para pengguna yang menggunakan sistem,

2) Prosedur dan instruksi yang digunakan untuk mengumpulkan, memproses, dan menyimpan data,

3) Data yang berisikan tentang organisasi serta kegiatan bisnisnya,

4) Perangkat lunak yang digunakan untuk memproses data,

5) Infrastruktur teknologi informasi, yang di dalamnya termasuk komputer, perangkat periferal, dan perangkat komunikasi jaringan yang digunakan dalam mengolah sistem informasi akuntansi, dan

6) Pengendalian internal dan prosedur kemanan guna melindungi sistem informasi akuntansi.

Fungsi Sistem Informasi Akuntansi

Fungsi penting yang dibentuk Sistem Informasi Akuntansi pada sebuah organisasi antara lain : Untuk mengumpulkan dan menyimpan data tentang aktivitas dan transaksi, Memproses data menjadi into informasi yang dapat digunakan dalam proses pengambilan keputusan, dan Melakukan kontrol secara tepat terhadap aset organisasi. Sedangkan menurut Azhar Susanto (2013:8) menyatakan bahwa fungsi sistem informasi akuntansi adalah : Mendukung aktivitas sehari-hari perusahaan, Mendukung proses pengambilan keputusan, dan Membantu dalam memenuhi tanggung jawab pengelolaan perusahaan. (Paulus, 2016) ${ }^{4}$

Sedangkan apabila menurut Romney \& Steinbart (2018:11) mengatakan bahwa 
keenam komponen sistem informasi akuntansi dapat memungkinkan sistem informasi akuntansi untuk memenuhi tiga fungsi bisnis penting, yaitu sebagai berikut : Mengumpulkan dan menyimpan data mengenai kegiatan yang dilakukan organisasi, sumber daya, serta personil dari organisasi. Organisasi memiliki sejumlah proses bisnis, seperti misalnya melakukan penjualan dan pembelian bahan baku dengan proses yang sering dilakukan secara berulang, Mengubah data menjadi informasi sehingga manajemen dapat merencanakan, melaksanakan, mengendalikan, dan mengevaluasi kegiatan, sumber daya, dan personil orangnisasi, dan Memberikan pengendalian yang memadai untuk melindungi aset dan data organisasi.

\section{Tujuan Sistem Informasi Akuntansi}

Dalam memenuhi kebutuhan informasi, baik untuk kebutuhan pihak eksternal maupun pihak internal, sistem informasi akuntansi harus didesain sedemikian rupa dan sebak mungkin, sehingga dapat memenuhi fungsinya. Demikian pula suatu sistem informasi akuntansi dalam memenuhi fungsinya harus mempunyai tujuan-tujuan yang dapat menghasilkan informasi-informasi yang berguna. Terutama dalam menunjang perencanaan dan pengendalian. Terdapat tiga tujuan sistem informasi akuntansi menurut (mardi, 2011:4), yaitu sebagai berikut :

1) Berguna untuk memenuhi setiap kewajiban sesuai dengan otoritas yang diberikan kepada seseorang (to fulfill obligations relating to stewardship). Pengelolaan perusahaan selalu mengacu kepada tanggung jawab manajemen atau keuangannya guna menata secara jelas segala sesuatu yang berkaitan dengan sumber daya yang dimiliki oleh perusahaan. Selain itu, keberadaan sistem informasi akuntansi dapat membantu ketersediaan informasi yang dibutuhkan oleh pihak ekternal melalui laporan keuangan modern dengan menggunakan dan memanfatkan tekonologi yang ada. Demikian pula ketersediaan laporan internal yang dibutuhkan oleh seluruh jajaran atau perusahaan dalam bentuk laporan pertanggungjawaban pengelolaan perusahaan.

2) Setiap informasi yang dihasilakan merupakan bahan yang berharga bagi pengambilan keputusan manajemen atau bagian keuangan suatu perusahaan (to support decision making by internal decision makers). Sistem informasi menyediakan informasi berguna mendukung setiap keputusan yang diambil oleh pimpinan sesuai dengan pertanggungjawaban yang telah ditetapkan.

3) Sistem informasi diperlukan dan dibutuhkan untuk mendukung kelancaran dari sbeuah 
operasional perusahaan sehari-hari (to support theday-to-day operations).

Manfaat Pengguanaan Sistem Informasi Akuntansi

Sistem informasi akuntansi yang dirancang dengan baik dapat memberikan manfaat serta menambah nilai untuk suatu pengguna atau organisasi dengan cara : Meningkatkan kualitas dan mengurangi biaya dari produk atau layanan (jasa) yang dipakai, Meningkatkan efisiensi dan efektifitas, Berbagi pengetahuan, Meningkatkan efisiensi dan efektivitas rantai pasokannya (supply chains), Memperbaiki struktur pengendalian internal, dan untuk meningkatkan kemampuan organisasi untuk pengambilan keputusan. Romney \& Steinbart (2018:11)

\section{Ruang Lingkup Sistem Informasi Akuntansi}

Ruang lingkup sistem informasi akuntansi mengalami perubahan yang sangat cepat dan drastis. Sejak perkembangan teknologi computer atau digital yang dapat mengolah data dengan cepat, tepat dan tidak mengenal lelah, berkembang pula informasi yang dapat dihasilkan dari akuntansi dan berkembang juga pemakai-pemakai sistem informasi akuntansi tersebut. Komputer atau teknologi digital merupakan alat bantu yang tepat untuk menyelesaikan permasalahan ini. Peranan computer atau digital saat sekarang terasa sangat besar san sangat penting bila benar-benar dapat memanfaatkannya dengan baik dan sistem informasi akuntansi sekarang selalu dikaitkan dengan penggunaan computer atau teknologi digital. Selain itu, sekarang, sistem informasi tidak hanya terlibat dalam aspek finansial saja, tetapi pada aspek manajemen juga lebih ditekankan dan penting. Sistem Informasi Akuntansi saat sekarang ini melibatkan tidak hanya sistem akuntansi keuangan saja namun, tetapi juga sistem akuntansi manajerial. Jadi sebenarnya Sistem Informasi Akuntansi merupakan sistem akuntansi dengan pengembangan informasi lebih luas dengan lebih menekankan informasi kepada manajemen tanpa mengurangi informasi kepada pihak luar.( Jogiyanto, 2000:53.)

\section{Karakteristik Sistem Informasi}

Untuk mendukung terbentuknya suatu sistem informasi, terdapat sembilan karakteristik sebagaimana yang dikemukakan di bawah ini. Menurut Mulyanto (2009:2), karakteristik system informasi terdiri dari sembilan bagian, yaitu: Mempunyai Komponen Sistem (Component System), Mempunyai Batasan Sistem (Boundary), Mempunyai Lingkungan (Environment), Mempunyai Penghubung (Interface) Antar Komponen, 
Mempunyai Masukan (Input), Mempunyai Pengolahan (Processing), Mempunyai Sasaran (Objective) dan Tujuan (Goal), Mempunyai Keluaran (Output), Mempunyai Umpan Balik (Feedback). Karakteristik sistem informasi di atas dapat dijelaskan dan diuraikan sebagai berikut:

1) Mempunyai Komponen Sistem (Component System) : Merupakan suatu system yang tidak berada di dalam lingkungan yang kosong, akan tetapi sebuah system informasi yang berada dan berfungsi di dalam lingkungan dan berisi tentang system informasi lainnya. Suatu sistem terdiri dari sejumlah komponen yang saling berinteraksi, bekerjasama untuk membentuk satu kesatuan. Apabila suatu sistem merupakan salah satu dari komponen sistem lain yang lebih besar, maka akan disebut dengan subsistem, sedangkan sistem yang lebih besar tersebut merupakan lingkungannya.

2) Mempunyai Batasan Sistem (Boundary) : Batas sistem merupakan pembatas atau pemisah antara suatu sistem dengan sistem yang lainnya atau pembatas dengan lingkungan luarnya.

3) Mempunyai Lingkungan (Environment) : Lingkungan luar merupakan apa pun di luar batas dari sistem yang dapat mempengaruhi operasi sistem, baik pengaruh yang menguntungkan ataupun pengaruh yang merugikan. Pengaruh yang menguntungkan ini tentunya harus dijaga sehingga akan mendukung kelangsungan operasi sebuah system tersebut berlangsung dnegan baik. Sedangkan lingkungan yang merugikan harus ditahan dan dikendalikan agar tidak mengganggu kelangsungan sebuah sistem.

4) Mempunyai Penghubung (Interface) Antar Komponen : Penghubung (interface) merupakan sebuah media penghubung antara satu subsistem dengan subsistem yang lainnya. Penghubung inilah yang nantinya akan menjadi media yang digunakan data dari masukan (input) hingga data keluaran (output). Dengan adanya penghubung ini, maka suatu subsistem dapat berinteraksi dan berintegrasi dengan subsistem yang lain utnuk membentuk satu kesatuan baik.

5) Mempunyai Masukan (Input) : Masukan atau input merupakan energi yang dimasukkan ke dalam sistem. Masukan dapat berupa masukan perawatan (maintenance input), yaitu bahan yang dimasukkan agar sistem tersebut dapat beroperasi dan masukan sinyal (signal input), yaitu masukan yang diproses untuk mendapatkan suatu keluaran.

6) Mempunyai Pengolahan (Processing) : Pengolahan (process) merupakan bagian yang melakukan perubahan dari masukan untuk menjadi keluaran yang memang diinginkan.

7) Mempunyai Sasaran (Objective) dan Tujuan (Goal) : Suatu sistem pasti memiliki sasaran 
(objective) atau tujuan (goal). Apabila sistem tidak mempunyai sasaran, maka operasi sistem tidak akan ada gunanya dan bisa dibilang tanpa arah. Tujuan inilah yang nantinya akan mengarahkan suatu sistem. Dengan tanpa adanya suatu tujuan, maka system akan menjadi tidak terarah dan terkendali.

8) Mempunyai Keluaran (Output) : Keluaran (output) merupakan hasil dari pemprosesan. Keluaran ini dapat berupa informasi sebagai masukan pada sistem lain atau hanya sebagai sisa pembuangan saja.

9) Mempunyai Umpan Balik (Feedback) : Umpan balik diperlukan oleh bagian kendali (control) sistem untuk mengecek apakah ada terjadinya penyimpangan proses dalam suatu sistem dan mengembalikannya ke dalam kondisi normal atau dalam kondisi baik.

\section{B. Sistem Penggajian (Gaji) dan Pengupahan (Upah)}

Pengertian Sistem Penggajian dan Pengupahan

Sistem penggajian dan pengupahan dalam suatu perusahaan sangat dibutuhkan, karena dengan adanya sistem penggajian dan pengupahan ini dapat mengorganisir proses penerimaan atau pemberian gaji dan upah pada setiap orang yang bekerja di dalam suatu perusahaan, sehingga dapat memberikan efisiensi dan efektivitas dalam proses penggajian dan pengupahan tersebut.

Sistem akuntansi penggajian menurut (Mulyadi, 2016:373) merupakan sebuah fungsi, dokumen, catatan, dan sistem pengendalian intern yang digunakan untuk kepentingan harga pokok produk dan penyediaan informasi guna pengawasan biaya tenaga kerja. Sistem akuntansi penggajian dan pengupahan ini dirancang untuk menangani transaksi perhitungan gaji dan upah karyawan dan pembayarannya. Sistem ini terdiri dari jaringan prosedur yaitu: Prosedur pencatatan waktu hadir, Prosedur pembuatan daftar gaji, Prosedur distribusi biaya gaji, Prosedur pembuatan bukti kas keluar, dan prosedur pembayaran gaji (Mulyadi, 2016:385).

Pengertian penggajian (gaji) merupakan suatu sistem yang mengatur tata cara pemberian gaji/upah kepada segenap karyawan dalam organisasi. Di samping itu, gaji dan upah dikenal pula dengan istilah penghasilan bersih, atau juga disebut dengan imbal jasa. Sedangkan pengertian pengupahan (upah) merupakan hak yang dimiliki oleh pekerja atau karyawan yang diterima dan dinyatakan dalam bentuk uang sebagai bentuk imbalan dari pengusaha atau pemberi kerja kepada pekerja yang ditetapkan dan dibayarkan menurut suatu perjanjian kerja, kesepakatan atau peraturan perundang-undangan, termasuk juga 
tunjangan bagi pekerja dan keluarganya atas suatu pekerjaan dan atau jasa yang telah atau akan dilakukan tersebut. Selain itu pengertian sistem akuntansi penggajian dan pengupahan meruapakan sebuah sistem akuntansi penggajian dan pengupahan dalam perusahaan jasa kontruksi melibatkan fungsi karyawan, keuangan dan fungsi akuntansi. (Prianthara 2013:137)

Dalam proses penggajian dan pengupahan membutuhkan banyak dokumendokumen atau prosedur-prosedur dalam pelaksanaannya, oleh karena itu sangat diperlukan dibuatnya Sistem Informasi Akuntansi Penggajian dan Pengupahan di setiap perusahaan atau organisasi yang efektif dan efisien baik juga dalam proses pelaksanaannya. Dapat disimpulkan bahwa Sistem Informasi Akuntansi Penggajian dan Pengupahan merupakan suatu sistem yang dirancang untuk membuat informasi-informasi tentang penggajian dan pengupahan, dimana disusun dan dilaksanakan secara sistematis sesuai dengan sistem akuntansi yang baik dan benar.

Fungsi-Fungsi Yang Terkait Sistem Akuntasi Penggajian Dan Pengupahan

Fungsi-fungsi umum yang terkait dengan sistem akuntansi penggajian dan pengupahan sangat diperlukan ketepatan dalam pemilihan fungsi yang nantinya akan digunakan tersebut, jangan sampai ada fungsi yang telah dipilih namun dalam penggunaan fungsi tersebut kurang efektif dan efisien, sehingga fungsi tersebut nantinya akan mengganggu dalam sebuah penerapannya. Namun, fungsi tersebut bisa digantikan dengan fungsi yang lainnya. Menurut (Mulyadi, 2016:317) fungsi yang biasanya di gunakan dalam suatu perusahaan adalah sebagai berikut, yaitu :

1) Fungsi Kepegawaian : Fungsi ini bertanggungjawab untuk mencari karyawan baru, menyeleksi calon karyawan, memutuskan penempatan posisi karyawan, membuat surat keputusan tarif gaji dan upah karyawan, kenaikan pangkat dan golongan gaji, mutasi karyawan, dan pemberhentian karyawan.

2) Fungsi Pencatat Waktu : Fungsi ini bertanggungjawab untuk menyelenggarakan catatan waktu hadir bagi semua karyawan perusahaan. Sistem pengendalian internal yang baik mensyaratkan fungsi pencatatan waktu hadir karyawan tidak boleh dilaksanakan oleh fungsi operasi atau oleh fungsi pembuat daftar gaji dan upah atau bisa disebut dengan fungsi ganda.

3) Fungsi Pembuat Daftar Gaji dan Upah : Fungsi ini bertanggungjawab untuk membuat daftar gaji dan upah yang berisi penghasilan bruto yang menjadi hak dan berbagai 
potongan yang menjadi beban setiap karyawan selama jangka waktu pembayaran gaji dan upah. Daftar gaji dan upah diserahkan oleh fungsi pembuat daftar gaji dan upah kepada fungsi akuntansi untuk pembuatan bukti kas keluar yang nantinya dipakai sebagai dasar untuk pembayaran gaji dan upah kepada karyawan.

4) Fungsi Akuntansi Dalam sistem akuntansi penggajian dan pengupahan : fungsi atau bagian akuntansi ini bertanggungjawab penuh untuk mencatat kewajiban yang timbul dalam hubungannya dengan pembayaran gaji dan upah karyawan (misalnya utang gaji dan upah karyawan, utang pajak, dan ataupun utang dana pensiun). Fungsi akuntansi yang menangani sistem akuntansi penggajian dan pengupahan meliputi yaitu :

a) Bagian Utang : Bagian ini berfungsi untuk memegang pencatatan utang yang dalam sistem akuntansi penggajian dan pengupahan bertanggung jawab untuk memproses pembayaran gaji dan upah. Bagian ini menerbitkan bukti kas keluar yang memberi otorisasi kepada fungsi pembayar gaji dan upah untuk membayarkan gaji dan upah kepada karyawan.

b) Bagian Kartu Biaya : Bagian ini memegang fungsi akuntansi biaya yang dalam sistem akuntansi penggajian dan pengupahan bertanggung jawab untuk mencatat distribusi biaya ke dalam kartu harga pokok produk dan kartu biaya berdasarkan rekap daftar gaji dan upah dan kartu jam kerja (untuk tenaga kerja langsung pabrik).

c) Bagian Jurnal Bagian ini memegang fungsi pencatat jurnal yang bertanggung jawab untuk mencatat biaya gaji dan upah dalam jurnal umum.

5) Fungsi Keuangan Fungsi ini bertanggungjawab untuk mengisi cek guna pembayaran gaji dan upah dan menguangkan cek tersebut ke bank. Utang tunai tersebut kemudian dimasukkan ke dalam amplop gaji dan upah setiap karyawan, untuk selanjutnya dibagikan kepada karyawan yang berhak.

Dokumen Yang Digunakan Dalam Sistem Penggajian Dan Pengupahan

Dokumen dalam sistem penggajian dan pengupahan sebaiknya lengkap dan transparan, agar tidak terjadi kecurangan-kecurangan yang tidak diinginkan. dokumen yang digunakan dalam sistem penggajian dan pengupahan adalah:

1) Dokumen Pendukung Perubahan Gaji dan Upah Dokumen ini umumnya dikeluarkan oleh fungsi kepegawaian berupa surat keputusan yang bersangkutan dengan karyawan.

2) Kartu Jam Hadir Dokumen digunakan oleh fungsi pencatat waktu untuk mencatat jam hadir setiap karyawan di perusahaan. Catatan jam hadir ini dapat berupa daftar hadir 
biasa atau berbentuk kartu hadir yang diisi dengan mesin pencatat waktu.

3) Kartu Jam Kerja Dokumen ini digunakan untuk mencatat waktu yang dikonsumsi oleh tenaga kerja langsung pabrik guna mengerjakan pesanan tertentu. Dokumen ini diisi oleh mandor dan diserahkan ke fungsi pembuat daftar gaji dan upah untuk distribusi biaya upah langsung kepada setiap jenis produk.

4) Daftar Gaji dan Daftar Upah Dokumen ini berisi jumlah gaji dan upah bruto setiap karyawan, dikurangi potongan-potongan berupa PPh pasal 21, utang karyawan, iuran untuk organisasi karyawan, dan lain sebagainya.

5) Rekap Daftar Gaji dan Rekap Daftar Upah Dokumen ini merupakan ringkasan gaji dan upah per departemen yang dibuat berdasarkan daftar gaji dan upah. Dalam perusahaan yang produksinya berdasarkan pada pesanan, rekap gaji dan upah dibuat untuk membebankan upah langsung dalam hubungannya dengan produk kepada pesanan yang bersangkutan. Distribusi biaya tenaga kerja ini dilakukan oleh fungsi akuntansi biaya dengan rekap daftar gaji dan upah.

6) Surat Pernyataan Gaji dan Upah Dokumen ini dibuat oleh fungsi pembuat daftar gaji dan upah bersamaan dengan pembuatan daftar gaji dan upah atau dalam kegiatan yang terpisah dari pembuatan daftar gaji dan upah. Dokumen ini dibuat sebagai catatan bagi setiap karyawan mengenai rincian gaji dan upah yang diterima setiap karyawan besert berbagai potongan yang menjadi beban setiap karyawan.

7) Amplop Gaji dan Upah Uang gaji dan upah karyawan diserahkan setiap karyawan dalam amplop gaji dan upah. Di halaman depan amplop gaji dan upah setiap karyawan ini berisi informasi mengenai nama karyawan, nomor identifikasi karyawan dan jumlah gaji bersih yang diterima karyawan dalam periode tertentu.

8) Bukti Kas Keluar Dokumen ini merupakan perintah pengeluaran uang yang dibuat oleh fungsi/departemen keuangan berdasarkan informasi dalam daftar gaji dan upah yang diterima dari fungsi pembuat daftar gaji dan upah.

Keseluruhan dokumen-dokumen tersebut harus disiapkan agar proses sistem informasi penggajian dan pengupahan dilaksanakan secara efektif dan efisien tanpa adanya kesalahan ataupun kekurangan sedikitpun.

\section{Catatan Akuntansi Yang Digunakan Dalam Sistem Penggajian dan Pengupahan}

Catatan-catatan akuntansi yang digunakan dalam sistem penggajian dan pengupahan harus dibuat dengan baik dan tersimpan dengan aman, karena catatan-catatan tersebut 
merupakan bukti yang nyata atas setiap transaksi yang berhubungan dengan penggajian dan pengupahan dalam perusahaan tersebut, dan juga dapat menghindarkan perusahaan dari kerugian atau kecurangan-kecurangan yang bisa saja terjadi. Mulyadi (2016:382) menyatakan bahwa catatan akuntansi yang digunakan dalam sistem penggajian dan pengupahan meliputi:

1) Jurnal Umum : Jurnal umum digunakan untuk mencatat distribusi biaya tenaga kerja dalam tiap departemen di perusahaan.

2) Kartu Harga Pokok Produk : Catatan ini digunakan untuk mencatat upah tenaga kerja langsung yang dikeluarkan untuk pesanan tertentu.

3) Kartu Biaya : Catatan ini dipergunakan untuk mencatat biaya tenaga kerja tidak langsung dan biaya tenaga kerja nonproduksi setiap departemen dalam perusahaan. Sumber informasi untuk pencatatan dalam kartu biaya ini adalah bukti memorial.

4) Kartu Penghasilan Karyawan : Catatan mengenai penghasilan dan berbagai potongan yang diterima oleh setiap karyawan. Informasi dalam kartu penghasilan karyawan ini dipakai sebagai dasar perhitungan PPh pasal 21. Kartu penghasilan karyawan digunakan juga untuk tanda terima gaji dan upah karyawan dengan ditandatangani kartu tersebut oleh karyawan yang bersangkutan.

\section{METODE PENELITIAN}

Model metode penelitian yang dipakai adalah deskriptif analisis dengan pendekatan kualitatif yang bertujuan mendeskripsikan dan menggambarkan informasi yang ada. Metode deskriptif yaitu merupakan penelitian dengan data kualitatif yang kemudian diolah dan dianalisis untuk diambil kesimpulan. Sumber dan jenis data yang digunakan dalam penelitian ini adalah data sekunder. Data sekunder merupakan sumber data penelitian, yang diperoleh melalui media perantara atau orang lain, atau secara tidak langsung yang berupa buku, catatan, bukti yang telah ada, atau arsip yang telah dipublikasikan maupun yang tidak dipublikasikan secara umum. Metode analisis yang digunakan adalah metode analisis interaktif, dengan analisa model interaktif yang dikembangkan oleh Milles dan Hubberman (dalam Moleong :307), yang terdiri dari 3 komponen analisis yaitu:

1) Reduksi data, yaitu proses pemilihan, pemberian fokus, penyederhanaan dan transformasi data mentah terdapat di lapangan. Hal ini bertujuan untuk mempertajam, menggolongkan, menyortir dan mengorganisasikan data. 
2) Penyajian data, yaitu proses penyusunan informasi yang kompleks ke dalam bentuk yang sistematis dan memberi kemungkinan adanya penarikan kesimpulan dan pengambilan keputusan. Bentuk paling umum yang digunakan berupa teks uraian.

3) Penarikan kesimpulan/verifikasi, merupakan akhir kegiatan analisis berupa penarikan kesimpulan dengan cara meninjau ulang data-data yang diperoleh dilapangan agar data tersebut valid.

Sifat-sifat evaluasi menurut William N. Dunn (2003 : 608) sebagai berikut:

1) Fokus Nilai. Evaluasi berbeda dengan pemantauan, dipusatkan pada penilaian menyangkut keperluan atau nilai dari suatu kebijakan dan program.

2) Interdependensi Fakta Nilai.

3) Orientasi Masa Kini dan Masa Lampau.

4) Kualitas Nilai.

Sedangkan metode deskriptif menurut Sugiyono adalah: "Metode yang digunakan untuk menggambarkan atau menganalisis suatu hasil penelitian tetapi tidak digunakan untuk membuat kesimpulan yang lebih luas". Selain itu, Sugiono juga mengemukakan bahwa pendekatan kualitatif sebagai metode penelitian yang berlandaskan pada filsafat postpositivisme, digunakan untuk meneliti pada kondisi objek alamiah, dimana peneliti adalah sebagai instrumen kunci, teknik pengumpulan data dengan triangulasi, analisis dat bersifat induktif atau kualitatif, daan hasil penelitian kualitatif lebih menekankan makna daripada generalisasi. Penelitian ini menafsirkan dan menguraikan data yang bersangkutan dengan situai yang sedang terjadi kemudian membandingkannya dengan peraturan yang sudah ditetapkan. (Pabowo \& Eldon, $2018)^{5}$

\section{HASIL PENELITIAN DAN PEMBAHASAN}

\section{A. Analisis Pelaksanaan Penggajian Karyawan Tetap dan Karyawan Harian}

Karyawan tetap dan borongan tetap melakukan absensi harian tetapi hanya untuk mengetahui tingkat kehadiran dari karyawan yang bersangkutan. Sebaiknya daftar hadir karyawan tetap digunakan sebagai acuan penentuan besarnya gaji yang diterima. Meskipun gaji kar yawan tetap dan karyawan borongan sudah ditetapkan oleh perusahaan sebaiknya rekap absen tetap dilakukan dan digunakan sebagai dasar penentuan jumlah gaji yang diberikan 
apabila tingkat kehadiran karyawan tidak memenuhi standart. Sehingga apabila karyawan yang bersangkutan tidak hadir atau absen melebihi jumlah hari libur yang diperbolehkan oleh perusahaan maka akan mempengaruhi besarnya gaji yang diberikan dengan melakukan perhitungan gaji berdasarkan daftar hadir dari karyawan yang bersangkutan. Tidak dijadikannya daftar hadir karyawan sebagai bahan pertimbangan dalam menentukan besarnya gaji menimbulkan tidak diketahuinya tingkat kedisiplinan karyawan.

Tetapi absen dengan menggunakan sistem check clock rawan dengan tindak kecurangan yaitu titip absen, dimana karyawan dapat meminta rekan karyawan lainnya untuk terlebih dahulu mengabsenkan apabila terlambat atau berhalangan hadir. Kelemahan pelaksanaan penggajian karyawan harian adalah yang melakukan rekap daftar hadir adalah bagian akuntansi bukan bagian administrasi keuangan. Dimana bagian akuntansi juga bertanggung jawab melakukan rekap daftar hadir. Penggajian bagi para karyawan didasarkan pada kemampuan suatu lembaga sebagai standar gaji pokoknya, kemudian ditambah tunjangan jabatan, tunjangan transport, uang makan, dan premi hadir, selanjutnya dikurangi dengan potongan gaji seperti utang gaji karyawan. Ketentuan besarnya tunjangan yang diberikan kepada karyawan ini diperhitungkan berdasarkan jabatan dan masa kerja karyawan yang bersangkutan. Besar gaji pokok yang diterima masing - masing karyawan ditentukan oleh pihak manajemen sesuai jabatan masing - masing karyawan.

\section{B. Analisis Fungsi - Fungsi yang Terkait dalam Sistem Informasi Akuntansi Penggajian dan Pengupahan.}

Fungsi - fungsi yang terkait dalam sistem informasi akuntansi penggajian pada PT. Populer Sarana Medika adalah :

1) Bagian Akuntansi Bagian akuntansi bertugas untuk membuat rekap daftar hadir karyawan, daftar gaji karyawan, slip gaji, lembar penerimaan gaji, bukti kas keluar, dan bertanggung jawab mencatat transaksi - transaksi penggajian pada jurnal umum dan buku besar.

2) Direktur Direktur berwenang dalam proses pembayaran gaji pokok karyawan. Melakukan transfer gaji pokok, tunjangan jabatan, tunjangan transport, uang makan, dan premi hadir ke rekening masing - masing karyawan dan mentransfer biaya pembayaran pendapatan per bulan ke rekening Bagian Akuntansi melalui E-bankin ( Electronic Banking ).

3) Fungsi Kepegawaian. Fungsi ini sudah berjalan dengan baik, namun masih 
diperlukan pengembangan kemampuan sumber daya manusia untuk mereka yang bertugas mengelola data Sistem Informasi Akuntansi Penggajian dan Pengupahan.

4) Fungsi Pencatat Waktu Pencatat waktu yang ada telah dilakukan dengan baik, karena telah menggunakan sistem finger print,dimana dilakukan dengan menempelkan jari atau sidik jari sebagai tanda hadir pegawai. Sistem finger print ini sangat berguna dan bermanfaat karena dapatmenghindari terjadinya kecurangan kecurangan dalam absensi, seperti adanya penitipan tandatangan pegawai, dimana pegawai tersebut sebenarnya tidak hadir namun didaftar hadir memilik itanda bahwa pegawai tersebut hadir, kecurangan kecurangan seperti ini yang harus dikurangi.

5) Fungsi Pembuat Daftar Gaji Dan Upah, bertanggung jawab untuk membuat daftar gaji dan upah yang berisi penghasilan bruto yang menjadi hak dan berbagai potongan yang menjadi beban setiap karyawan selama jangka waktu pembayaran gaji dan upah.

6) Fungsi Akuntansi, Fungsi proses akuntansi juga bisa menjadi dasar perhitungan pajak dan untuk menentukan kebijakan manajemen perusahaan. Fungsi akuntansi yang menangani system akuntansi penggajian dan pengupahan meliputi bagian utang, kartu biaya, dan bagian jurnal. Penjelasannya yaitu:

a) Bagian Utang : Bagian ini memegang fungsi pencatat utang yang dalam sistem akuntansi penggajian dan pengupahan bertanggung jawab untuk memproses pembayaran gaji dan upah seperti yang tercantum dalam daftar gaji dan upah. Bagian ini menerbitkan bukti kas keluar yang memberi otorisasi kepada fungsi pembayar gaji dan upah untuk membayarkan gaji dan upah kepada karyawan seperti yang tercantum dalam daftar gaji dan upah tersebut.

b) Bagian Kartu Biaya : Bagian ini memegang fungsi akuntansi biaya yang dalam sistem akuntansi penggajian dan pengupahan bertanggung jawab untuk mencatat distribusi biaya ke dalam kartu harga pokok produk dan kartu biaya berdasarkan rekap daftar gaji dan upah dan kartu jam kerja (untuk tenaga kerja langsung pabrik).

c) Bagian Jurnal :Bagian ini memegang fungsi pencatat jurnal yang bertanggung jawab untuk mencatat biaya gaji dan upah dalam jurnal umum.

7) Fungsi Keuangan, fungsi keuangan dalam perusahaan ini erat hubungannya dengan pendanaan perusahaan itu sendiri. Atau dalam kata lain, tujuan dari manajemen keuangan ini adalah memaksimalkan atau memberikan nilai tambah terhadap aset- 
aset yang dimiliki perusahaan. Fungsi ini bertanggungjawab untuk mengisi cek guna pembayaran gaji dan upah dan menguangkan cek tersebut ke bank. Utang tunai tersebut kemudian dimasukkan ke dalam amplop gaji dan upah setiap karyawan, untuk selanjutnya dibagikan kepada karyawan yang berhak.

Alternatif - alternatif untuk mengurangi kelemahan pada fungsi - fungsi yang terkait dalam sistem informasi akuntansi penggajian antara lain :

1) Terdapat bagian khusus seperti fungsi pembuat daftar gaji (bagian akuntansi) yang bertanggung jawab untuk membuat daftar gaji yang berisi gaji pokok serta tunjangan-tunjangan yang diberikan kepada karyawan dan potongan-potongan yang menjadi beban karyawan setiap bulannya. Daftar gaji tersebut dikelola oleh fungsi pembuat daftar gaji guna pembuatan daftar gaji yang akan diajukan ke kasir, untuk pembayaran gaji pegawai.

2) Selain itu, harus ada fungsi pencatat waktu (bagian personalia) yang bertanggungjawab untuk membuat rekap daftar hadir karyawan dan menyelenggarakan waktu hadir bagi semua karyawan PT. Populer Sarana Medika. Sistem pengendalian intern yang baik mensyaratkan fungsi pencatatan waktu hadir karyawan tidak boleh dilaksanakan oleh fungsi operasi atau oleh fungsi pembuat daftar gaji dan upah.

\section{Analisis Dokumen - Dokumen yang Digunakan dalam Sistem Informasi Akuntansi Penggajian dan Pengupahan.}

Untuk sistem gaji, dokumen-dokumen yang digunakan dalam sistem gaji sudah efektif dan efisien, karena dokumendokumen sistem gaji yang umumnya harus digunakan sudah lengkap. Untuk sistem upah, yaitu dokumen dokumen yang digunakan dalam upah belum efektif, karena pegawai honor yang menerima upah dalam Rumah Sakit masih jarang terjadi, sehingga dokumendokumen tersebut jarang digunakan dan biasanya menggunakan dokumen atau cara manual yang lebih simple. Dokumen dokumen lainnya meliputi :

1) Daftar Hadir Karyawan

Data yang diperoleh dari sistem absensi ini mencakup jam kedatangan dan kepulangan pegawai yang ada. Dari absensi ini juga bisa diketahui penyebab ketidakhadiran seorang karyawan apakah dia sakit atau izin karena suatu keperluan. Adanya data ini akan memudahkan pemilik usaha dalam menghitung jumlah gaji yang diperoleh setiap pegawai. Beberapa pemilik usaha yang sudah menerapkan sistem absensi canggih berbasis teknologi, jam lembur pegawai juga bisa secara 
otomatis terdata. Dengan begitu nilai uang lembur juga akan langsung masuk saat proses penghitungan gaji di akhir bulan.

2) Rekap Daftar Hadir Karyawan

Laporan juga berisikan informasi tentang waktu hadir dan pergi karyawan termasuk keterlambatan. Secara umum dalam laporan ini biasanya akan mencatatkan beberapa data terkait kehadiran karyawan seperti :

a) Data cuti atau izin karyawan.

b) Data karyawan datang dan pulang ( clock in / clock out)

c) Mencatat data karyawan datang terlambat.

d) Pada kasus sistem online, akan terdapat fitur pendukung remote working atau

Lalu ada banyak manfaat dari penggunaan laporan ini, juga beberapa jenis absensi yang biasa digunakan di perusahaan. Laporan juga membantu perusahaan untuk tetap meng-engaged karyawan dengan terus meningkatkan produktivitas. Perusahaan perlu mengetahui karyawan mana yang bekerja, kapan mereka bekerja dan kapan mereka biasanya mengambil cuti tahunan mereka. Karena pada kenyataannya, absensi berdampak besar terhadap biaya perusahaan jika dibandingkan dengan tunjangan karyawan.

3) Daftar Gaji Karyawan

Fungsi pemberian laporan gaji dari pemberi kepada karyawan adalah sebagai informasi yang transparan sekaligus bukti tertulis apabila suatu saat timbul persepsi yang berbeda antara pemberi kerja dan karyawan mengenai hak-hak karyawan yang belum dan sudah dibayarkan. Bukti tertulis ini dianggap bukti yang otentik untuk menunjukkan bahwa hak karyawan atas upah telah dipenuhi oleh pemberi kerja.

4) Slip Gaji

Slip gaji adalah bukti pembayaran upah. Dokumen ini disusun bersamaan dengan penggajian, sehingga tanggal yang tertera pada slip gaji juga merupakan tanggal upah dibayarkan secara langsung atau melalui bank. Dengan diserahkannya slip gaji, maka perusahaan sudah memenuhi hak karyawan paling pokok, yaitu membayar upah. Laporan gaji karyawan atau yang sering juga disebut dengan slip gaji merupakan bukti otentik dan informasi resmi pembayaran gaji dari pemberi kerja kepada karyawan. Pada laporan upah ini biasanya tertera rincian penghasilan sekaligus potongan-potongan dari perusahaan. Sehingga karyawan dapat mengetahui secara transparan penghasilan neto yang diterimanya.

5) Dokumen Pendukung Perubahan Gaji dan Upah

Dokumen ini umumnya dikeluarkan oleh fungsi kepegawaian berupa surat 
keputusan yang bersangkutan dengan karyawan.

6) Kartu Jam Hadir

Dokumen digunakan oleh fungsi pencatat waktu untuk mencatat jam hadir setiap karyawan di perusahaan. Catatan jam hadir ini dapat berupa daftar hadir biasa atau berbentuk kartu hadir yang diisi dengan mesin pencatat waktu.

7) Kartu Jam Kerja

Dokumen ini digunakan untuk mencatat waktu yang dikonsumsi oleh tenaga kerja langsung pabrik guna mengerjakan pesanan tertentu. Dokumen ini diisi oleh mandor dan diserahkan ke fungsi pembuat daftar gaji dan upah untuk distribusi biaya upah langsung kepada setiap jenis produk

8) Bukti Kas Keluar

Dokumen ini merupakan perintah pengeluaran uang yang dibuat oleh fungsi/departemen keuangan berdasarkan informasi dalam daftar gaji dan upah yang diterima dari fungsi pembuat daftar gaji dan upah.

Keseluruhan dokumen-dokumen tersebut harus disiapkan agar proses system informasi penggajian dan pengupahan dilaksanakan secara efektif dan efisien.

\section{Analisis Jaringan Prosedur Yang Digunakan}

Dalam sistem gaji, jaringan prosedur sistem gaji yang ada sudah berjalan dengan efektif namun belum efisien, karena sebaiknya prosedur dokumen dafar gaji, rekap gaji dan penerimaan gaji dilakukan oleh satu bagian saja, agar data-data yang ada dapat dengan cepat diproses dan diolah. Dalam sistem upah, jaringan prosedur untuk sistem upah sudah dibuat dengan efektif dan efisien, namun pelaksanaannya masih saja tidak sesuai dengan prosedur yang telah dibuat. Pembayaran tunjangan karyawan dan transfer gaji pokok ke rekening masing - masing karyawan dilakukan oleh Kasir dan rekap daftar hadir karyawan dilakukan oleh bagian personalia. Prosedur pencatatan waktu hadir karyawan masih terdapat kelemahan yaitu pengawasan pengisian daftar hadir karyawan dan rekap daftar hadir karyawan masih dilakukan oleh bagian akuntansi. Pengisian daftar hadir karyawan sebaiknya diawasi oleh Bagian Personalia. Rekap daftar hadir karyawan sebaiknya juga dibuat oleh Fungsi pencatat waktu. (Fibriyanti, 2017)6

\section{E. Analisis Catatan Akuntansi Yang Digunakan}


Catatan catatan akuntansi suatu perusahaan harus disesuaikan dengan dikumen dokumen dan jaringan yang ada di dalam perusahaan tersebut. Dapat terdiri dari Jurnal umum dan buku besar yang dibuat untuk merekam transaksi yang berkaitan dengan pemberian gaji karyawan. Catatan akuntansi yang digunakan dalam sistem penggajian dan pengupahan meliputi:

1) Jurnal Umum : Jurnal umum digunakan untuk mencatat distribusi biaya tenaga kerja dalam tiap departemen di perusahaan.

2) Kartu Harga Pokok Produk : Catatan ini digunakan untuk mencatat upah tenaga kerja langsung yang dikeluarkan untuk pesanan tertentu.

3) Kartu Biaya : Catatan ini dipergunakan untuk mencatat biaya tenaga kerja tidaklangsung dan biaya tenaga kerja nonproduksi setiap departemen dalam perusahaan. Sumber informasi untuk pencatatan dalam kartu biaya ini adalah bukti memorial.

4) Kartu Penghasilan Karyawan : Catatan mengenai penghasilan dan berbagai potongan yang diterima oleh setiap karyawan. Informasi dalam kartu penghasilan karyawan ini dipakai sebagai dasar perhitungan $\mathrm{PPh}$ pasal 21. Kartu penghasilan karyawan digunakan juga untuk tanda terima gaji dan upah karyawan dengan ditandatangani kartu tersebut oleh karyawan yang bersangkutan.

\section{F. Analisis Efektivitas Pengendalian Intern dalam Sistem Informasi Akuntansi Penggajian dan Pengupahan}

1) Struktur Organisasi : Dalam sistem pengendalian yang baik fungsi pembuat daftar gaji harus terpisah dari fungsi pencatat waktu, begitu juga dengan fungsi keuangan dan juru bayar yang harus terpisah agar tidak mengakibatkan kecurangan. Oleh karena itu maka peneliti mengusulkan penambahan sub bagian admin keuangan yang bertugas mengelola keuangan, dan pencatat waktu.

2) Sistem Otorisasi dan Pencatatan : Dengan adanya dokumen - dokumen dalam sistem informasi akuntansi penggajian yang digunakan sebagai bukti penting yang berkaitan dengan prosedur penggajian karyawan.

3) Praktek yang sehat

a) Ketelitian dan kebenaran perhitungan daftar gaji dihitung kembali kebenarannya oleh Bagian Akuntansi sebelum melakukan pembayaran gaji 
kepada karyawan.

b) Pembayaran gaji pokok karyawan dilakukan dengan mentransfer uang gaji ke rekening masing - masing karyawan oleh Direktur.

c) Slip gaji dibuat rangkap dua. Lembar kesatu disimpan oleh Bagian Akuntansi lembar kedua untuk diberikan kepada masing - masing karyawan.

Harus dilakukannya pengecekan kembali perhitungan gaji atau pendapatan per bulan oleh Bagian Akuntansi sebelum dibayarkan ke masing - masing karyawan karena bagian akuntansi bertanggung jawab dalam pembuatan daftar gaji per bulan karyawan. Bagian Akuntansi juga bertanggung jawab membuat slip gaji yang dibuat dua rangkap dimana lembar kesatu disimpan oleh Bagian Akuntansi dan diberikan kepada masingmasing karyawan. Pembayaran gaji pokok karyawan dilakukan dengan mentransfer uang gaji ke rekening masing-masing karyawan oleh Direktur melalui E-banking (Electronic banking).

\section{KESIMPULAN DAN SARAN}

\section{A. Kesimpulan}

1) Sistem Informasi Akuntansi Penggajian dan Pengupahan yang diterapkan dan diimplementasikan pada perusahaan harus berisi fungsi-fungsi, dokumen, jaringan prosedur yang digunakan dan catatan akuntansi yang digunakan terkait system penggajian dan pengupahan sudah sesuai dengan fungsi, dokumen, jaringan prosedur dan catatan akuntansi yang dibutuhkan.

2) Untuk menghindari penyelewengan harus menghindari kerangkapan tugas pada bagian administrasi keuangan dan melakukan pemisahan fungsi yang jelas antara atasan dan bawahan serta pembagian tugas dan tanggungjawabnya yang baik kepada tiap tiap karyawan.

3) Sistem pengendalian intern merupakan proses pemantauan yang memungkinkan manajemen mengetahui apakah tindakan yang dilakukan dan bagaimanakah tindakan koreksinya jika pelaksanaan tidak sesuai dengan yang telah ditetapkan semula. Suatu sistem pengendalian intern dikatakan memadai jika dengan diterapkannya sistem tersebut semua tujuan perusahaan dapat tercapai. 


\section{B. Saran}

1) Ada baiknya jika perusahaan melakukan pelatihan secara berkesinambungan terhadap SDM yang mengolah data tentang gaji dan upah, agar data tentang gaji dan upah tersebut dapat diolah dengan baik, dan menghasilkan system informasi akuntansi penggajian dan pengupahan yang lebih efektif dan efisien.

2) Jaringan prosedur yang digunakan terkait system gaji sebaiknya lebih di efisienkan dalam penggunaannya, agar data yang dihasilkan lebih tepat dan dapat diproses dengan cepat, tanpa perlu dilakukannya pengiriman data ke jaringan prosedur lainnya yang akan menghabiskan banyak waktu.

3) Dalam sistem informasi akuntansi penggajian, sebaiknya perlu adanya pemisahan tugas dan wewenang yang jelas sehingga perangkapan fungsi dapat diminimalkan serta dapat meningkatkan pengendalian intern perusahaan. Dokumen yang digunakan dalam sistem akuntansi penggajian dan pengupahan karyawan hendaknya mendapat otorisasi dari bagian yang bertanggungjawab agar dapat mencegah adanya penyelewengan.

4) Untuk memudahkan manajemen melakukan pengawasan terhadap jalannya operasional perusahaan maka diperlukan bagian khusus yang menangani masalah pengendalian intern perusahaan, karena dalam bagian ini terdapat bagian khusus yang mengawasi bagian keuangan, personalia, serta operasional perusahaangian. 


\section{DAFTAR PUSTAKA}

Fibriyanti, Y. V. (2017). ANALISIS SISTEM INFORMASI AKUNTANSI PENGGAJIAN DALAM RANGKA EFEKTIVITAS PENGENDALIAN INTERNAL PERUSAHAAN (Studi Kasus pada PT. Populer Sarana Medika, Surabaya). Jurnal Akuntansi, 2(1), 14. https://doi.org/10.30736/jpensi.v2i1.97

Hidayat, M. (2013). ANALISIS PENERAPAN SISTEM AKUNTANSI PENGGAJIAN DAN PENGUPAHAN DALAM MENDUKUNG PENGENDALIAN INTERN (Studi Kasus pada PT. Cahaya Marta Perkasa, Pamekasan). Jurnal Administrasi Bisnis S1 Universitas Brawijaya, 6(2), 78098.

Jeklin, A. (2016). BAB III LANDASAN TEORITIS. July, 1-23. (Jeklin, 2016)

Pabowo, R. G. M., \& Eldon, M. (2018). Kajian Pengetahuan Dalam Manajemen Bencana Di Kabupaten Tulungagung. Jurnal BENEFIT, 5(1), 60-77. http://www.jurnalunita.org/index.php/benefit/article/view/159

Paulus, A. (2016). Fungsi Sistem Informasi Akuntansi Atas Pengendalian Internal Pendapatan (Studi Kasus Pada Rumah Sakit Siloam Manado). Jurnal Riset Ekonomi, Manajemen, Bisnis Dan Akuntansi, 4(4), 922-931. https://doi.org/10.35794/emba.v4i4.14531

Purba, D. (2018). Sistem Informasi Akuntansi Penggajian Dan Pengupahan. Sistem Informasi Akuntasi, 4, 15-22. http://ejournal.Imiimedan.net/index.php/jm/article/view/26/24 (Purba, 2018)

Randi.M. (2018). BAB II TINJAUAN PUSTAKA. Journal of Chemical Information and Modeling, 53(9), 1689-1699.

Romney, \& Steinbart. (2018). Sitem Informasi Akuntasi. Pengertian Sistem Informasi Akuntasi, 6(11), 951-952. http://library.binus.ac.id/eColls/eThesisdoc/Bab2/RS1_2018_1_1044_Bab2.pdf

(Romney \& Steinbart, 2018) 